\title{
Histone acetylation and arachidonic acid cytotoxicity in HepG2 cells overexpressing CYP2E1
}

\author{
A. Holownia • R. M. Mroz • P. Wielgat • P. Jakubow • \\ J. Jablonski • J. Sulek • J. J. Braszko
}

Received: 26 July 2013 / Accepted: 14 November 2013 / Published online: 28 November 2013

(C) The Author(s) 2013. This article is published with open access at Springerlink.com

\begin{abstract}
The aim of this work was to assess the role of ethanol-derived acetate and acetate-mediated histone acetylation in arachidonic acid-induced stress in HepG2 cells and cells overexpressing CYP2E1. Cells were grown for 7 days with $1 \mathrm{mM}$ sodium acetate or $100 \mathrm{mM}$ ethanol; their acetylated histone proteins and histone deacetylase 2 expression was quantified using Western blot. Ethanol- or acetate-pretreated cells were also treated for $24 \mathrm{~h}$ with $60 \mu \mathrm{M}$ arachidonic acid to induce oxidative stress. Cytotoxicity was estimated by lactate dehydrogenase release, 3-[4,5-dimethylthiazolyl-2] 2,5-diphenyltetrazolium bromide test, and by DNA damage, while oxidative stress was quantified using dichlorofluorescein diacetate. Cells grown with ethanol or acetate had increased acetylated histone H3 levels in both cell types and elevated acetylated histone H4 levels in cells overexpressing CYP2E1 but not in naïve cells. In cells overexpressing CYP2E1 grown with ethanol, expression of histone deacetylase 2 was reduced by about $40 \%$. Arachidonic acid altered cell proliferation and was cytotoxic mostly to cells engineered to overexpress CYP2E1 but both effects were significantly lower in cells pretreated with ethanol or acetate. Cytotoxicity was also significantly decreased by 4-methylpyrazole - a CYP2E1 inhibitor and by trichostatin - an inhibitor of histone deacetylases. In cells pretreated with acetate or ethanol, the oxidative stress induced by arachidonic acid was also significantly lower. Our
\end{abstract}

A. Holownia $(\bowtie) \cdot$ P. Wielgat $\cdot$ P. Jakubow $\cdot$ J. Sulek $\cdot$ J. J. Braszko Department of Clinical Pharmacology, Medical University of Bialystok, Waszyngtona 15A, 15-274 Bialystok, Poland e-mail: Holow_sinai@hotmail.com

R. M. Mroz

Department of Pneumology, Medical University of Bialystok, Zurawia 14, 15-540 Bialystok, Poland

J. Jablonski

Department of Toxicology, Medical University of Bialystok, Mickiewicza 2c, 15-089 Bialystok, Poland data indicate that histone hyperacetylation may in some extent protect the cells against oxidative stress. It is possible that acetate may act as an antioxidant at histone level. This mechanism may be relevant to alcohol-induced liver injury.

Keywords Arachidonic acid - CYP2E1 - Cytotoxicity · Ethanol $\cdot$ HepG2 cells $\cdot$ Histone acetylation

\section{Introduction}

Ethanol is metabolized in the liver by alcohol dehydrogenase, cytochrome P4502E1, and catalase-producing acetaldehyde, which is further oxidized by aldehyde dehydrogenase to acetate. Acetate is considered as not toxic and it is mostly removed in Krebs cycle as acetylCoA (Cederbaum 2012); however, it was shown that ethanol-derived acetate can acetylate different proteins, and acetylated cytosolic, mitochondrial, and nuclear hepatic proteins have been detected in liver samples from patients with alcoholism and in experimental animals intoxicated with ethanol (Shepard and Tuma 2009). Ethanol-derived acetate can acetylate such important proteins like tumor suppressor p53 protein, sterol response element binding protein-1c, peroxisome proliferator-activated receptor $\gamma$ coactivator $\alpha$ (PGC-1 $\alpha), \alpha$-tubulin, mitochondrial acetyl CoA synthetase 2, and others (Shepard and Tuma 2009). The first hyperacetylated liver protein which was detected in an animal model of both acute and chronic alcohol intoxication was a nuclear histone H3 protein (Park et al. 2003). Histones are important in all aspects of cell physiology and pathology because they are involved in regulation of gene transcription. Histone-DNA complexes are usually transcriptionally activated by histone acetylation, but functional regulation of histone protein is also controlled by methylation and other reactions important in epigenetic regulations (Zentner and Henikoff 2013). Their role in alcohol-induced liver injury is 
still not assessed but several evidences stress important role of histone acetylation in inflammatory signaling and it seems that histone acetylation may also be relevant to alcoholic hepatitis and cirrhosis. It was shown that acetate generated in alcohol metabolism increased histone acetylation and expression of inflammatory cytokines pointing to important role of hyperacetylation of core histones in alcoholic hepatitis (Mandrekar and Szabo 2009; Kendrick et al. 2010; Mandrekar 2011). Histones can be transcriptionally silenced by deacetylation, which is mediated by histone deacetylases (HDACs) and it was shown that deregulation of HDAC, probably due to oxidative stress, could play a major role in the binge alcohol-induced hepatic steatosis and liver injury (Kirpich et al. 2012). Post-alcoholic liver damage is also associated to oxidative stress mediated in major part by CYP2E1 (Albano 2006). The role of histones in oxidative stress in less known, although recent data indicate that HDAC inhibition and histone hyperacetylation may significantly suppress oxidative stress induced by $\beta$-hydroxybutyrate (Shimazu et al. 2013). The objective of this work was to alter histone acetylation in cultured naïve HepG2 cells and HepG2 cells overexpressing alcohol metabolizing enzymeCYP2E1, by growing the cells in medium supplemented with ethanol or with acetate and to compare the effect of oxidative stress induced by arachidonic acid (AA) on cell growth and survival.

\section{Materials and methods}

Cells and reagents The human hepatoblastoma cell sublineHepG2 stably transfected with human CYP2E1 and HepG2 cells transfected with an empty vector with undetectable CYP2E1 activity were kindly provided by Professor A. Cederbaum of the Department of Pharmacology and Biological Chemistry, Mount Sinai School of Medicine in New York, USA. Cells were grown in minimal essential medium (MEM) supplemented with $10 \%$ fetal bovine serum, penicillin (100 U per $\mathrm{ml})$, and streptomycin (100 $\mu \mathrm{g}$ per $\mathrm{ml})$, at $37^{\circ} \mathrm{C}$ in a humidified atmosphere of $5 \% \mathrm{CO}_{2}$. For maintaining CYP2E1 expression, the medium was additionally supplemented with G418-sulfate ( $200 \mu \mathrm{g}$ per $\mathrm{ml})$, the antibiotic used for the selection process.

Cell treatment Cells were grown for 1,3, or 7 days in medium supplemented with $1 \mathrm{mM}$ sodium acetate (Sigma Chemical Co) or with $100 \mathrm{mM}$ ethanol and media were refreshed every $24 \mathrm{~h}$. Decline in ethanol levels after $24 \mathrm{~h}$ incubation was quantified using gas chromatography with mass spectrometry detection (Tsukamoto et al. 1998), and $24 \mathrm{~h}$ after ethanol treatment, ethanol levels in the culture media were decreased by about $65 \%$. Both HepG2 cells and transduced cells produced significant amounts of acetaldehyde and acetate as detected by gas chromatography-mass spectrometry, which confirmed earlier observations (Marselos et al. 1987; Wu et al. 2006). In some experiments, $5 \mathrm{mM}$ 4-methylpyrazole (4MP) was used for $24 \mathrm{~h}$ to inhibit CYP2E1 and $100 \mathrm{ng} / \mathrm{ml}$ trichostatin (TSA; $24 \mathrm{~h}$ ) to inhibit HDACs. None of the above treatments resulted in significant cytotoxicity basing on culture medium lactate dehydrogenase activity (LDH) assay. After preincubation of cells with ethanol or with acetate, cells were seeded into 6- or 25-well plates and were grown for additional $24 \mathrm{~h}$ in MEM medium supplemented with $60 \mu \mathrm{M}$ AA (Sigma Chemical Co).

Subcellular fractions and histone isolation To isolate cytosolic and nuclear fractions, cells were scraped, centrifuged, resuspended in cold hypotonic buffer containing $10 \mathrm{mM}$ HEPES, $\mathrm{pH} 7.9,1.5 \mathrm{mM} \mathrm{MgCl}_{2}, 10 \mathrm{mM} \mathrm{KCl}, 50 \mathrm{mM}$ dithiothreitol, $100 \mathrm{mM}$ phenanthroline, $1 \mathrm{mg} / \mathrm{ml}$ pepstatin, $100 \mathrm{mM}$ trans-epoxysuccinyl-L-leucylamido-(4-guanidino)butane, $100 \mathrm{mM} \mathrm{3,4-dichloroisocoumarin,} 10 \mathrm{mM} \mathrm{NaF}, 100 \mathrm{mM}$ sodium orthovanadate and $25 \mathrm{mM} \beta$-glycerophosphate, and centrifuged at $14,000 \times g$ for $5 \mathrm{~min}$ at $4{ }^{\circ} \mathrm{C}$. Then, cells were lysed in a solution of the same buffer containing $0.2 \%(v / v)$ Nonidet P-40 for 10 min on ice and subsequently centrifuged at $14,000 \times g$ for $10 \mathrm{~min}$ at $4{ }^{\circ} \mathrm{C}$. The supernatant was collected as cytosolic extract. The remaining pellet was resuspended in extraction buffer (20 mM HEPES, pH 7.9, $420 \mathrm{mM} \mathrm{NaCl}$, $1.5 \mathrm{mM} \mathrm{MgCl}_{2}, 0.2 \mathrm{mM}$ EDTA, $25 \%$ ( $\left.v / v\right)$ glycerol, $100 \mathrm{mM}$ 3,4-dichloroisocoumarin), incubated for $15 \mathrm{~min}$ at $4{ }^{\circ} \mathrm{C}$, and centrifuged at $14,000 \times g$ for $10 \mathrm{~min}$ at $4{ }^{\circ} \mathrm{C}$. The supernatant including soluble nuclear protein was collected as nuclear extract.

Acid extraction of histones was performed in cells treated for $30 \mathrm{~min}$ in ice with lysis buffer $10 \mathrm{mM}$ HEPES, $\mathrm{pH}$ 7.9, $1.5 \mathrm{mM} \mathrm{MgCl}_{2}, 10 \mathrm{mM} \mathrm{KCl}, 0.5 \mathrm{mM}$ DTT, and $1.5 \mathrm{mM}$ phenylmethylsulfonyl fluoride and hydrochloric acid at a final concentration of $0.2 \mathrm{M}$, and subsequently, lysed cells were centrifuged at $11,000 \times g$ for $10 \mathrm{~min}$ at $4{ }^{\circ} \mathrm{C}$. Supernatant containing acid-soluble proteins was dialyzed for $1 \mathrm{~h}$, against $0.1 \mathrm{M}$ acetic acid and then overnight against $\mathrm{H}_{2} \mathrm{O}$ and frozen until assayed (Chadee et al. 1999). Quantification of acetylated histones with broad range anti-acetylated histone antibodies and Western immunoblotting indicated that the highest increase in acetylated histones was obtained after 7 days of cell treatment with ethanol or acetate, thus 7 days treatment was used in all further experiments.

Western immunoblotting Specific proteins were analyzed by sodium dodecyl sulfate-polyacrylamide gel electrophoresis/ immunoblotting with appropriate rabbit antibodies (Santa Cruz Biotechnology, Heidelberg, Germany) recognizing HDAC2 protein (cytosol; sc-81599 antibody) or acetylated (Ser 11 and/or Lys 115) histone H3 (AcH3; sc-33361 antibody) and acetylated (Ser 1, Lys 5, Lys 8 and Lys 12) histone 
H4 (AcH4; sc-34263 antibody) (acid-extracted samples). Proteins were separated along with specific protein standards and molecular weight markers (Bio-Rad, Warsaw, Poland) in $10 \%$ (HDAC2) or $20 \%$ (acetylated histones) polyacrylamide gels. Gels were transferred onto $0.45-\mu \mathrm{m}$ PVDF membranes (BioRad, Warsaw, Poland). Species-specific horseradish peroxidase or alkaline phosphatase secondary antibodies were purchased from Santa Cruz or Sigma, respectively. Changes in $\mathrm{AcH} 3$ and $\mathrm{AcH} 4$ histone levels were analyzed comparing to total histone $\mathrm{H} 3$ and histone $\mathrm{H} 4$ levels (total human histone H3 and H4 antibodies were from Santa Cruz Biotechnology, Heidelberg, Germany; sc-8654 antibody and sc-10810 antibody, respectively). Loading controls for HDAC were done using B-actin. Protein bands were quantified using Quantity One software (BioRad, Warsaw, Poland). Samples were run in duplicate on each gel and mean values were expressed as 100 relative units $\pm \mathrm{SD}$ to compare data from different experiments.

Determination of cell viability Cell viability was primarily tested by time-dependent LDH release to the culture medium using LDH cytotoxicity kit (ScienCell, Carlsbad, USA), and then also by 3-[4,5-dimethylthiazolyl-2] 2,5-diphenyltetrazolium bromide (MTT) assay (Niks and Otto 1990) and by flow cytometry estimation of cell growth and cytotoxicity (Shapiro 1988). For the experiments, control cells or cells pretreated with ethanol or acetate were seeded on 24-well plates and treated with AA and LDH activity in the culture media was quantified after $1,3,6,12$, and $24 \mathrm{~h}$ according to manufacturers' instruction. $\mathrm{LDH}$ data were compared to total enzyme activity obtained after cell sonication.

MTT assay and flow cytometry were performed after $24 \mathrm{~h}$ of cell treatment with AA. In MTT test, changes in absorbance due to formazone production in viable cells were measured after $24 \mathrm{~h}$ of AA treatment at $570 \mathrm{~nm}$, with $630 \mathrm{~nm}$ as a reference wavelength. Cell viability was estimated as a percentage of the control. To quantify alterations in cell growth and cytotoxicity by flow cytometry, cells were stained for 30 min with propidium iodide (PI; $50 \mu \mathrm{g}$ per $\mathrm{ml}$ ) in TRIS buffer $(100 \mathrm{mM}$; $\mathrm{pH} 7.5)$, containing $0.1 \%$ potassium cyanide, $0.01 \%$ NP- $40,40 \mu \mathrm{g}$ per ml Type III-A RNAse, and $0.1 \% \mathrm{NaN}_{3}$. DNA profiles in particular cells and cell cycle analysis were performed on an aligned Coulter Epics Profile Flow Cytometer (Coulter, Hialeah, FL, USA) equipped with an argon laser operating at $488 \mathrm{~nm}$ with adjusted forward angle- and side light-scatter. PI fluorescence was measured in 5,000-10,000 cells and DNA fluorescence histograms were analyzed by cells cycle software (MultiCycle, Phoenix Flow Systems Inc, San Diego, CA, USA). The cells were quantified by their relative distribution in the hypodiploid ("early" GO/ G1 zone of the DNA fluorescence histograms), diploid (G0/ G1 zone - pre-DNA synthesis/resting), S-phase (DNA synthesis), and G2/M (post DNA synthesis/mitosis) phases of the cell cycle. The percentage of cells in the subdiploid regions of histograms was considered as an index of cytotoxicity while $\mathrm{S}+\mathrm{G} 2 / \mathrm{M}$ cell numbers were quantified as proliferation index.

Oxidative stress Intracellular generation of reactive oxygen intermediates was quantified in control cells and in cells treated with AA for 1, 3, 6, 12, and $24 \mathrm{~h}$ using dichlorodihydrofluorescein diacetate $\left(\mathrm{H}_{2} \mathrm{DCFDA}\right.$; Sigma Chem. Co.) (Ubezio and Tivoli 1994). Cells were loaded with $5 \mu \mathrm{M} \mathrm{H}_{2}$ DCFDA for $30 \mathrm{~min}$, washed, resuspended in phosphate-buffered saline, and assayed by flow cytometry. Green dichlorofluorescein (DCF) fluorescence was captured on F11 and registered as histograms of fluorescence distribution.

Protein levels Homogenate proteins were measured using BCA kit (Sigma-Aldrich, Poznan, Poland).

Data analysis Statistical analysis was performed with a statistics package- Statistica 6.0 software (Statsoft; Cracow, Poland) using one-way or two-way ANOVA followed by Bonferroni post tests for selected pairs of data. Results were expressed as mean of 6 to 10 assays \pm S.D. $P$ values less than 0.05 were considered statistically significant.

\section{Results}

Figure 1 shows acetylated histone $\mathrm{H} 3(\mathrm{AcH} 3)$ and acetylated histone H4 (AcH4) in HepG2 cells and HepG2 cells overexpressing CYP2E1 grown for 7 days in culture medium supplemented with $1 \mathrm{mM}$ acetate or $100 \mathrm{mM}$ ethanol. Both treatments increased $\mathrm{AcH} 3$ in transduced and nontransduced cells, while AcH4 levels were significantly increased in cells overexpressing CYP2E1 grown with acetate or ethanol, but not in naïve HepG2 cells. The highest expression of acetylated histones (increase by $73 \% ; P<0.01$ ) was detected in $\mathrm{H} 3$ protein in cells overexpressing CYP2E1 grown with ethanol and slightly lower AcH3 levels (increase by $53 \% ; P<0.05$ ) were found in the same cell type grown with acetate. Lower but statistically significant increases were observed in $\mathrm{AcH} 4$ levels, in cells engineered to overexpress CYP2E1 treated with ethanol or acetate (increase by about $40 \% ; P<0.05$ in both groups), while in nontransduced cells AcH4 levels were not affected.

HDAC expression was reduced by about $40 \%(P<0.01)$ only in cells overexpressing CYP2E1 treated with ethanol (Fig. 2).

Figure 3 shows time-dependent LDH release from HepG2 cells and HepG2 cells overexpressing CYP2E1 treated with $\mathrm{AA}$ and also from both cell types grown for 1 week prior to AA treatment with $100 \mathrm{mM}$ ethanol or $1 \mathrm{mM}$ acetate. $\mathrm{LDH}$ release after $24 \mathrm{~h}$ of AA treatment is also shown in Table 1. 
Fig. 1 Acetylated histone $\mathrm{H} 3$ $(\mathrm{AcH} 3)$ and histone $\mathrm{H} 4(\mathrm{AcH} 4)$ in HepG2 cells and HepG2 cells overexpressing CYP2E1 grown for 1 week in culture medium supplemented with $1 \mathrm{mM}$ acetate or $100 \mathrm{mM}$ ethanol.

Figures represent mean results \pm SD. Data are relative values (digitized relative density) expressed as percentages over untreated cells taken as $100 \%$. Representative Western blot pictures are included. Statistically significant differences from controls are indicated as: $* P<0.05$ or $* * P<0.01$
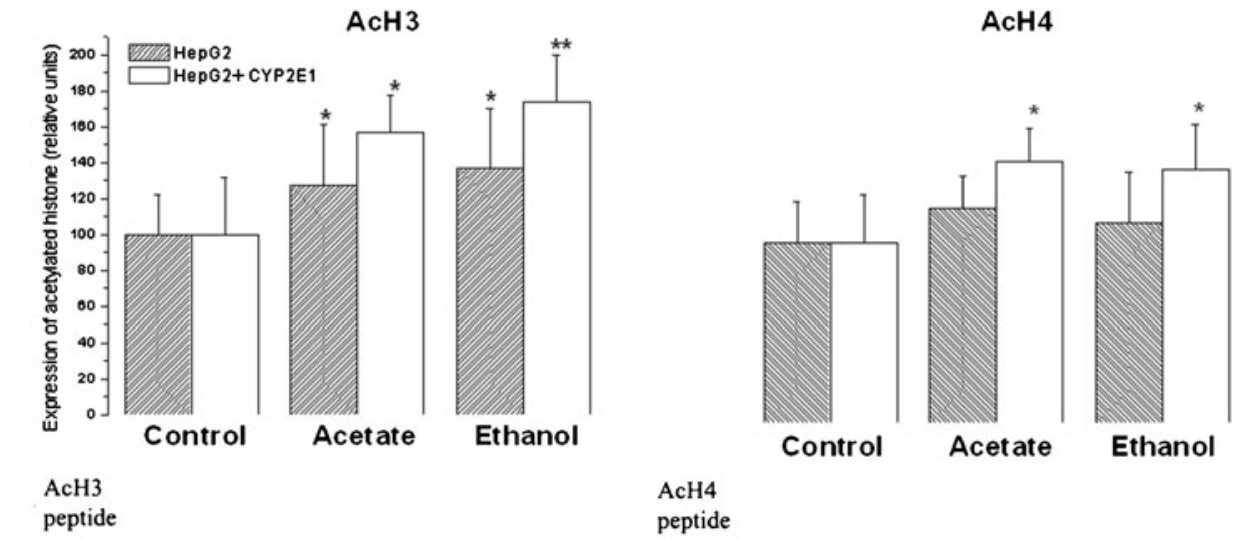

Neither ethanol nor acetate released LDH in both types of cells. AA treatment increased $(P<0.01) \mathrm{LDH}$ release to the culture medium of HepG2 cells treated with AA for $24 \mathrm{~h}$ (Fig. 3, Table 1) but in cells overexpressing CYP2E1 cell damage was increased already after $6 \mathrm{~h}$ of AA treatment and was still rising with time reaching at $24 \mathrm{~h}$ of AA treatment values about three times higher than in naïve HepG2 cells treated with AA $(P<0.01)$ or in control cells $(P<0.01)$. 4MP was without effect on LDH release induced by AA in HepG2 cells, while in transduced cells, AA cytotoxicity was decreased (Table 1) when AA was applied together with 4MP $(P<0.05)$ or when the cells were pretreated with
TSA $(P<0.05)$. Cells overexpressing CYP2E1 but not naïve cells grown with acetate or ethanol prior to AA treatment were also more resistant to AA $(P<0.01$ and $P<0.01$ for ethanol and acetate-pretreated cells, respectively).

Cytotoxicity of AA applied for $24 \mathrm{~h}$ to the cells was also tested by MTT test (Fig. 4). In HepG2 cells overexpressing CYP2E1, AA significantly decreased cell viability (by about $37 \% ; P<0.01)$. This effect was observed neither in naïve HepG2 cells nor in CYP2E1 overexpressing cells grown for 1 week with ethanol or acetate. Cytotoxicity of AA in transduced cells was abolished not only by CYP2E1 inhibitor4MP, but also by cell pretreatment with acetate or HDAC
Fig. 2 Histone deacetylase 2 (HDAC2) expression in HepG2 cells and HepG2 cells overexpressing CYP2E1 grown for 1 week in culture medium supplemented with $1 \mathrm{mM}$ acetate or $100 \mathrm{mM}$ ethanol.

Figures represent mean results \pm SD of five experiments. Data are shown as relative values (digitized relative density) expressed as percentages over untreated cells taken as $100 \%$. Representative Western blot picture is also included. Statistically significant difference from control is indicated as: ${ }^{* *} P<0.01$
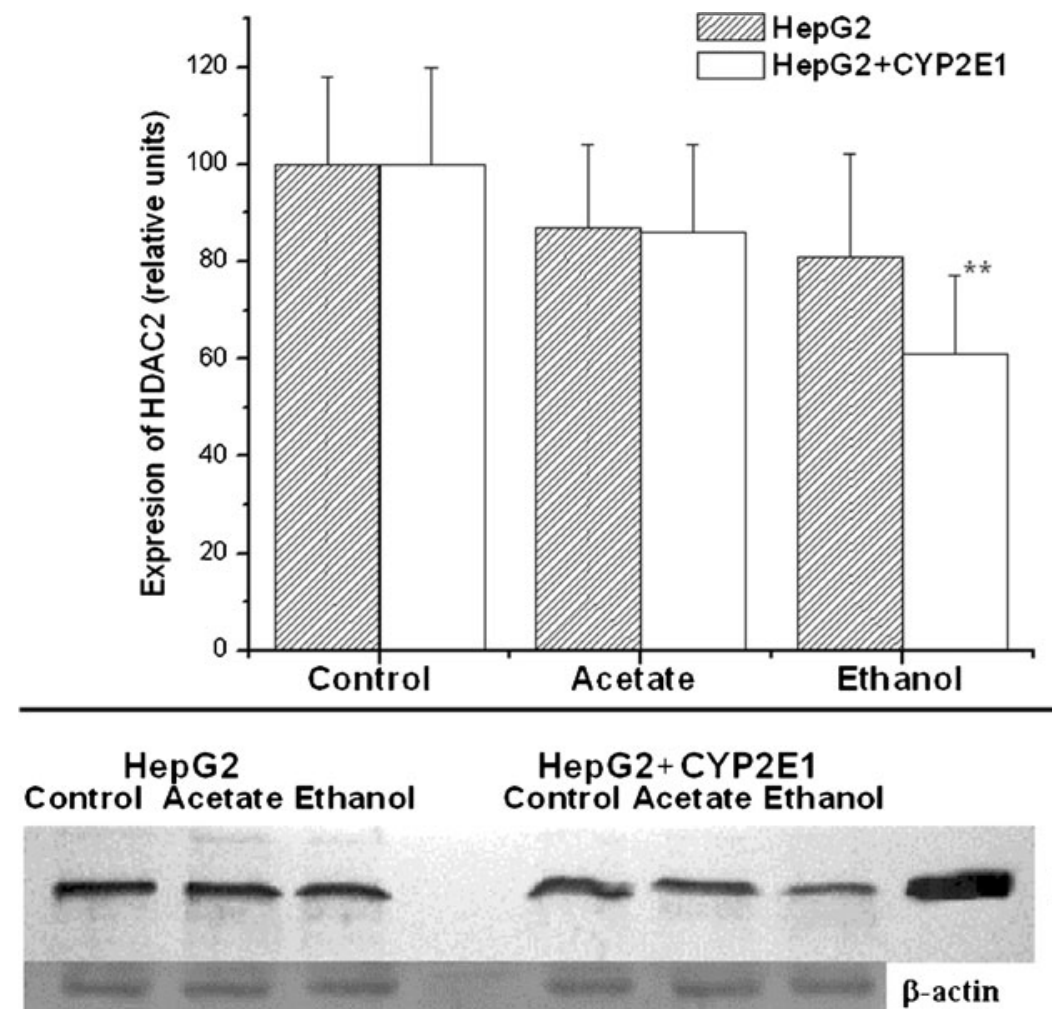
Fig. 3 The effect of arachidonic acid $(A A ; 60 \mu \mathrm{M})$ on viability of HepG2 and HepG2 cells overexpressing CYP2E1. Cell viability was assessed 1, 3, 6, 12, and $24 \mathrm{~h}$ after AA treatment using lactate dehydrogenase (LDH) assay. The same AA treatment was also done in cells grown prior to AA treatment for 1 week in culture medium supplemented with $1 \mathrm{mM}$ acetate $($ Acetate $+A A)$ or $100 \mathrm{mM}$ ethanol (Ethanol+ $A A$ ). Values of maximal LDH release reflecting total cell destruction were obtained after cell sonication. Each plotted point is a mean value from six experiments. Cytotoxicity data after $24 \mathrm{~h}$ of AA treatment are shown also in Table 1

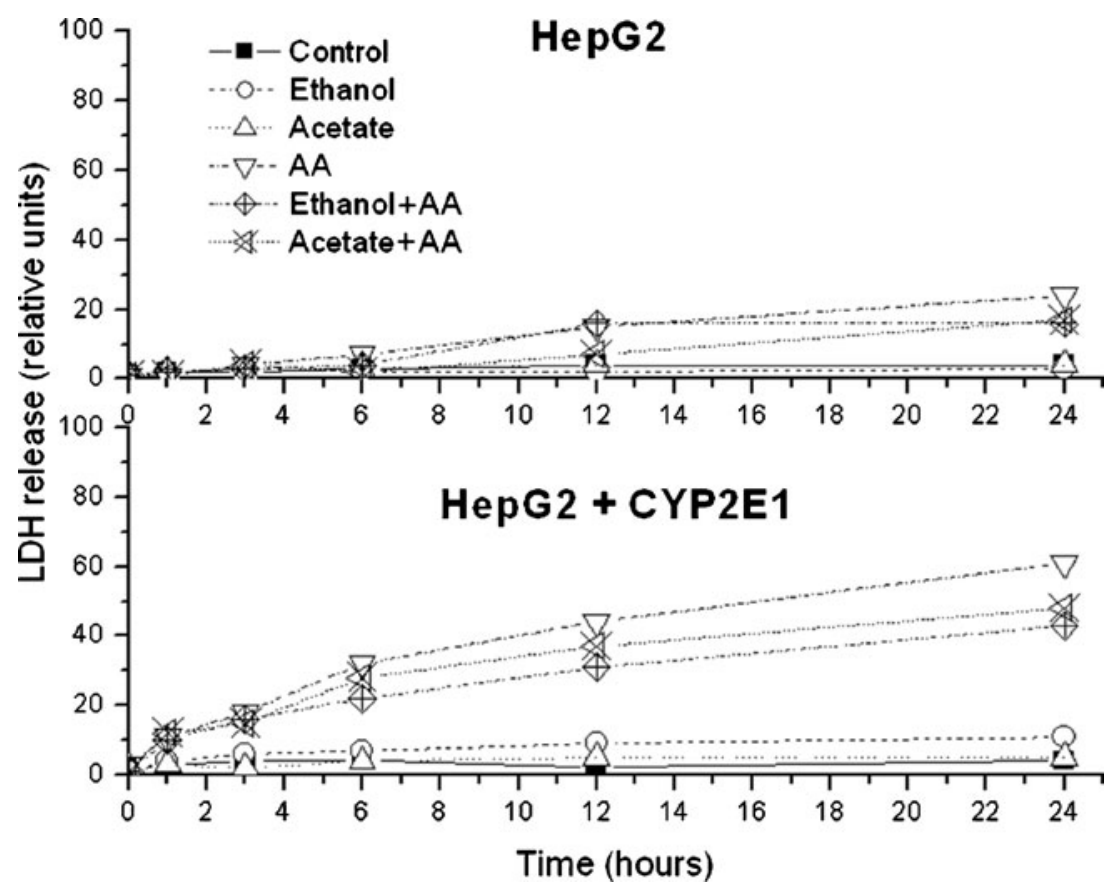

Table 1 Arachidonic acid (AA; $60 \mu \mathrm{M}, 24$ h)-induced lactate dehydrogenase $(\mathrm{LDH})$ release, cytotoxicity, alterations in cell proliferation $(\mathrm{S}+$ G2/M cells), and oxidative stress (DCF) in HepG2 cells and HepG2 cells overexpressing CYP2E1 and in the same cell types grown for 1 week prior to AA treatment in the culture medium supplemented with $100 \mathrm{mM}$ ethanol or $1 \mathrm{mM}$ acetate. In some experiments, cells were additionally treated for $24 \mathrm{~h}$ with both AA and with CYP2E1 inhibitor, 4methylpyrazole (4MP; $5 \mathrm{mM}$ ) or pretreated for $24 \mathrm{~h}$ before AA with trichostatin (TSA, $100 \mathrm{ng} / \mathrm{ml}$ ) to inhibit histone deacetylases. LDH activity in the culture medium was measured using a LDH cytotoxicity kit and results are expressed as a fraction of total enzyme activity acquired after cell sonication. To quantify oxidative stress, the cells were stained with dichlorofluorescein diacetate (DCF) and green fluorescence was captured in viable cells only using flow cytometry. Alterations in cell growth and AA cytotoxicity were tested in flow cytometry after cell staining with propidium iodide (PI) and analysis of DNA-PI fluorescence histograms using multicycle software. Table shows fractions of damaged cells (subdiploid-GO/G1zone of the DNA fluorescence histograms; Fig. 7- "early G0/G1 cells") and percentages of proliferating cells in S(DNA synthesis) + G2/M (post-DNA-synthesis/mitosis) phases of cell cycle (Fig. 7). Each PI fluorescence distribution histogram was derived from analysis of at least 5,000 cells and six samples were analyzed in each group. Table shows mean values $\pm \mathrm{SD}$
HepG2

LDH

\section{Damaged cells}

$(\%)$

Proliferation DCF
$(\mathrm{S}+\mathrm{G} 2 / \mathrm{M}$
cells; \%)

HepG2+CYP2E1

\begin{tabular}{lll}
\hline LDH $\quad$ Damaged cells (\%) & $\begin{array}{l}\text { Proliferation DCF } \\
(\mathrm{S}+\mathrm{G} 2 / \mathrm{M} \\
\\
\end{array}$ \\
& cells; \%)
\end{tabular}

\begin{tabular}{|c|c|c|c|c|c|c|c|c|}
\hline Control & $5 \pm 3$ & $5 \pm 1$ & $60 \pm 8$ & $100 \pm 18$ & $7 \pm 2$ & $5 \pm 2$ & $65 \pm 11$ & $134 \pm 21$ \\
\hline Ethanol & $8 \pm 2$ & $4 \pm 1$ & $62 \pm 9$ & $108 \pm 15$ & $9 \pm 4$ & $5 \pm 2$ & $66 \pm 10$ & $158 \pm 33$ \\
\hline Acetate & $6 \pm 2$ & $6 \pm 1$ & $61 \pm 9$ & $106 \pm 12$ & $8 \pm 4$ & $7 \pm 1$ & $62 \pm 13$ & $130 \pm 26$ \\
\hline $4 \mathrm{MP}$ & $11 \pm 6$ & $7 \pm 2$ & $48 \pm 9^{*}$ & $111 \pm 16$ & $13 \pm 8$ & $13 \pm 4^{*}$ & $47 \pm 11^{* *}$ & $137 \pm 23$ \\
\hline $\begin{array}{l}\text { TSA } \\
\text { AA }\end{array}$ & $\begin{array}{l}10 \pm 7 \\
20 \pm 8^{* *}\end{array}$ & $\begin{array}{c}9 \pm 2 \\
11 \pm 2^{* *}\end{array}$ & $\begin{array}{l}45 \pm 9^{*} \\
45 \pm 11\end{array}$ & $\begin{array}{l}104 \pm 15 \\
121 \pm 19\end{array}$ & $\begin{array}{l}12 \pm 7 \\
64 \pm 11^{* *}\end{array}$ & $\begin{array}{l}11 \pm 7^{*} \\
35 \pm 5^{* *}\end{array}$ & $\begin{array}{l}46 \pm 14^{*} \\
30 \pm 18^{* *}\end{array}$ & $\begin{array}{l}130 \pm 32 \\
571 \pm 72^{* *}\end{array}$ \\
\hline $\mathrm{AA}+4 \mathrm{MP}$ & $21 \pm 9^{* *}$ & $12 \pm 4^{* *}$ & $41 \pm 10^{*}$ & $126 \pm 21$ & $43 \pm 12^{* *} \dagger<\dagger \dagger$ & $22 \pm 5^{* * *<}$ & $33 \pm 13^{* *}$ & $243 \pm 39^{* *+\dagger<}$ \\
\hline $\begin{array}{l}\mathrm{AA}+\mathrm{TSA} \\
\text { Ethanol+AA }\end{array}$ & $\begin{array}{l}22 \pm 12^{* *} \\
20 \pm 5^{* * \# \#}\end{array}$ & $\begin{array}{l}13 \pm 6^{* *} \\
9 \pm 2^{* * \# \#}\end{array}$ & $\begin{array}{l}42 \pm 14^{*} \\
44 \pm 14\end{array}$ & $\begin{array}{l}112 \pm 23 \\
124 \pm 19\end{array}$ & $\begin{array}{l}47 \pm 11^{* * \dagger \perp} \\
47 \pm 10^{* * \# \dagger \dagger}\end{array}$ & $\begin{array}{l}21 \pm 11^{* *} \dagger \\
20 \pm 6^{* * \# \dagger \dagger}\end{array}$ & $\begin{array}{l}38 \pm 12^{* * \dagger} \\
34 \pm 17^{* *}\end{array}$ & $\begin{array}{l}355 \pm 51^{* *+\dagger \perp \perp} \\
426 \pm 65^{* * \#+\dagger \dagger}\end{array}$ \\
\hline Acetate $+\mathrm{AA}$ & $21 \pm 7^{* *++}$ & $11 \pm 24^{* *++}$ & $65 \pm 12^{\dagger}$ & $122 \pm 20$ & $51 \pm 9^{* * \#++\dagger \dagger}$ & $18 \pm 4^{* *+\dagger \dagger}$ & $50 \pm 17$ & $462 \pm 78^{* * \#++\dagger \dagger}$ \\
\hline
\end{tabular}

${ }^{*} P<0.05$ (vs. corresponding control); ${ }^{* *} P<0.01$ (vs. corresponding control); ${ }^{\#} P<0.05$ (vs. corresponding data from ethanol-treated cell); ${ }^{\# \# ~} P<0.01$ (vs. corresponding data from ethanol-treated cells); ${ }^{+} P<0.05$ (vs. corresponding data from acetate-treated cells); ${ }^{++} P<0.01$ (vs. corresponding data from acetate-treated cells); ${ }^{\dagger} P<0.05$ (vs. corresponding data from AA-treated cells) $;^{\dagger \dagger} P<0.01$ (vs. corresponding data from AA-treated cells); ${ }^{<} P<0.05$ (vs. corresponding data from 4MP-treated cells); ${ }^{<} P<0.01$ (vs. corresponding data from 4MP-treated cells); ${ }^{\perp} P<0.05$ (vs. corresponding data from TSAtreated cells); ${ }^{\perp \perp} P<0.01$ (vs. corresponding data from TSA-treated cells) 
Fig. 4 The effect of arachidonic acid $(A A ; 60 \mu \mathrm{M} ; 24 \mathrm{~h})$ on viability of HepG2 and HepG2 cells overexpressing CYP2E1. Cell viability was assessed with MTT test. The same treatment was done in cells grown for 1 week with medium supplemented with $1 \mathrm{mM}$ acetate or $100 \mathrm{mM}$ ethanol. Results from six independent experiments are expressed as mean percentages of viable cells \pm SD and control was taken as $100 \%$. Statistically significant difference from the control is indicated as $* P<0.05$ and ${ }^{\# \#} P<0.01$ - from ethanoltreated cells

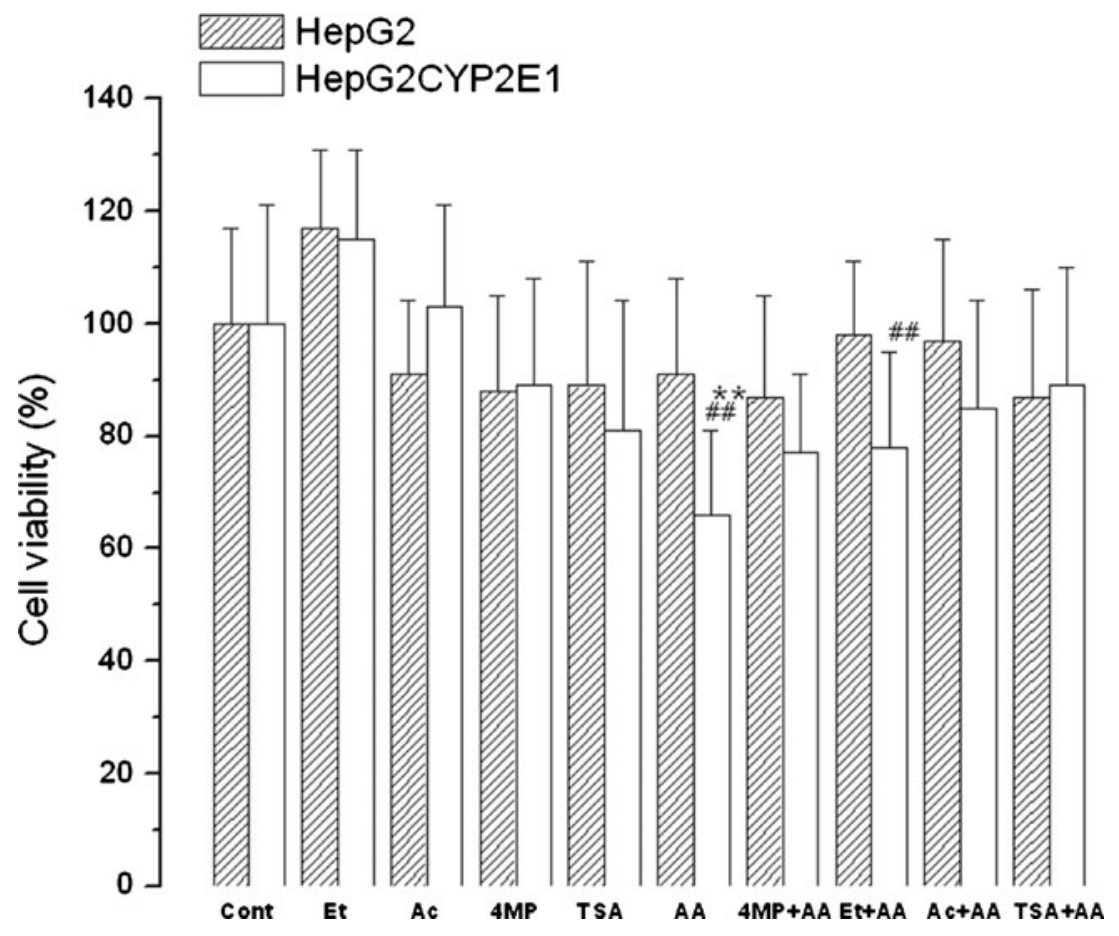

inhibitor-TSA (Table 1). In cells grown with ethanol prior to AA treatment, cytotoxicity of AA was slightly lower than in naïve cells but still significant $(P<0.01)$ comparing to ethanol-only treated cells.

Table 1 shows flow cytometry data of PI fluorescence reflecting cytotoxicity and proliferation of $\mathrm{HepG} 2$ cells or HepG2 cells overexpressing CYP2E1, and the same cell types grown for 1 week with $100 \mathrm{mM}$ ethanol or $1 \mathrm{mM}$ acetate and then treated for $24 \mathrm{~h}$ with AA as described in Materials and methods. Damaged cells were assessed as "early" G0/G1 cells and cell proliferation was quantified as $\mathrm{S}+\mathrm{G} 2 / \mathrm{M}$ cells (Fig. 5). Twenty-four hours of cell treatment with AA resulted in cytotoxicity in both cell types, but significantly higher toxicity was again observed in cells overexpressing CYP2E1. In HepG 2 cells, AA treatment produced about $11 \%$ of dead cells while in cells overexpressing CYP2E1 approximately $35 \%$ of cells were damaged. AA cytotoxicity was lower in CYP2E1expressing cells, which prior to AA treatment had grown with ethanol $(20 \%$ of dead cells; $P<0.01)$ or with acetate $(18 \%$ of dead cells, $P<0.01$ ), while in HepG2 cells, such protective effects were not observed. 4MP decreased AA cytotoxicity by about $35 \%(P<0.05)$ in transduced cells only and similar effect was observed when transduced cells were pretreated with TSA $(P<0.05)$.

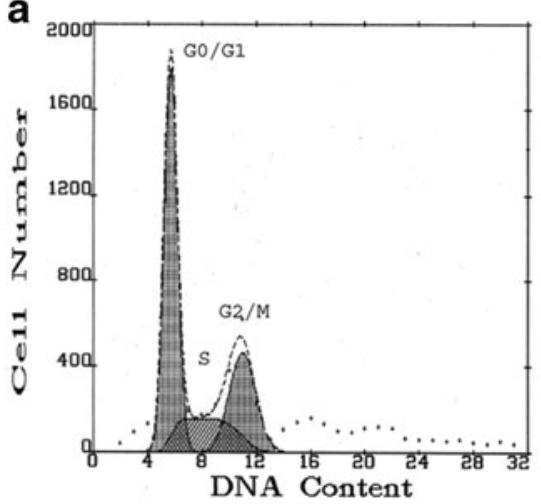

Fig. 5 Representative flow cytometry histograms of propidium iodide fluorescence distributions (MultiCycle transformation) in HepG2 cells overexpressing CYP2E1 (a) and in the same cells treated for $24 \mathrm{~h}$ with arachidonic acid (b). The cells were quantified by their relative distribution in the damaged-subdiploid GO/G1 zone of the DNA fluorescence histograms (early G0/G1 cells), diploid (G0/G1 zone)—pre-DNA b

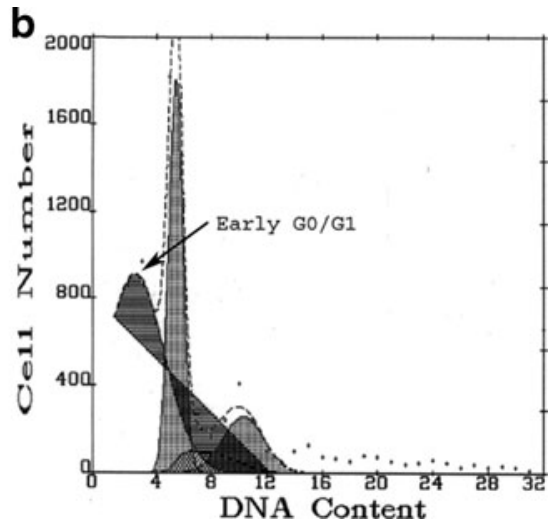

synthesis/resting, S-phase — DNA synthesis, and G2/M — post-DNA-synthesis/mitosis phases. Each histogram was derived from analysis of 5,000 cells and six samples were analyzed in each group. Quantification of cytotoxicity (early G0/G1 cells) and proliferation ( $\mathrm{S}+\mathrm{G} 2 / \mathrm{M}$ cells) is shown in Table 1 
AA decreased proliferating cell numbers by about $25 \%(P$ $<0.05)$ and $54 \%(P<0.01)$ in HepG2 cells and HepG2 cells expressing CYP2E1, respectively, and this effect was not significant in cells grown in acetate-supplemented media. Both 4MP and TSA decreased cell proliferation by about $30 \%$.

Ethanol itself only slightly but not significantly increased DCF fluorescence in nontransduced and transduced cells (Fig. 6, Table 1) while AA greatly increased oxidative stress only in cells overexpressing CYP2E1 reaching more than fourfold increase $(P<0.01)$ after $24 \mathrm{~h}$ of treatment. In transduced cells but not in HepG2 cells, DCF fluorescence was increased already after $3 \mathrm{~h}$ of AA treatment (Fig. 6). In contrast to naive cells, in transduced cells treated with AA a double peak fluorescence histograms appeared (Fig. 7, histogram C) representing two cell subpopulations - dead cells in the left part of histogram $\mathrm{C}$ and alive cells on the right side of the histogram C. AA-induced oxidative stress in transduced cells was reduced by 4MP and slightly less decreased by cell pretreatment with TSA (Table 1) but the fluorescence was not normalized. In cells overexpressing CYP2E1 grown with ethanol or with acetate prior to AA treatment, oxidative stress induced by AA was lower than in naïve cells, respectively, by $25 \%(P<0.01)$ and by $19 \%(P<0.01)$.

\section{Discussion}

Our data show that in cultured HepG2 cells grown for 7 days with ethanol or acetate, acetylated histone proteins are increased. Recent data point to alterations in histone acetylation

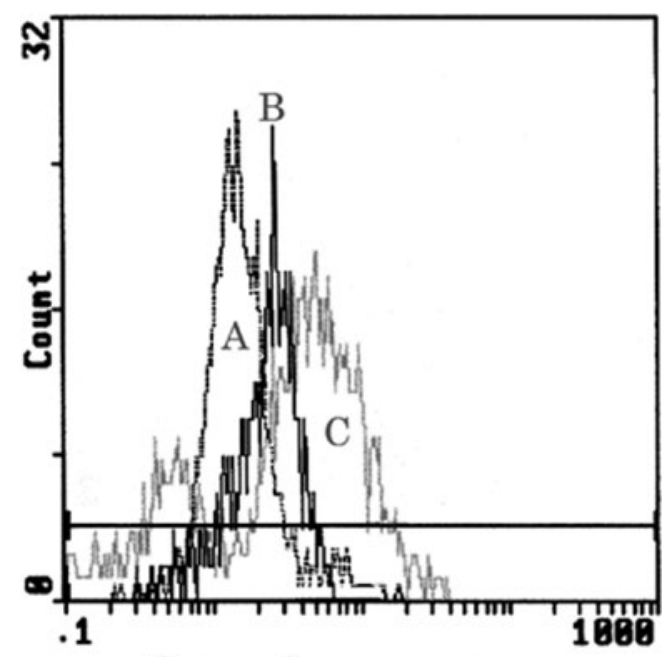

Green fluorescence

Fig. 7 Histograms of DCF fluorescence reflecting oxidative stress in HepG2 cells overexpressing CYP2E1 $(A)$ and the same cells treated for 6 $(B)$ or $24 \mathrm{~h}(C)$ with $60 \mu \mathrm{M}$ arachidonic acid (AA). After $6 \mathrm{~h}$ of cell treatment, increased oxidative stress (right shifted single peak fluorescence histogram B vs. A) was observed and after $24 \mathrm{~h}$ DCF fluorescence histograms were broad and double-peak representing (left part of histogram C) dead cell and (right part of histogram C) alive cells with high levels of oxidative stress

as a transcriptional mechanism modulating negative effects of oxidative stress. It was shown that $\beta$-hydroxybutyrate increased histone acetylation and provided substantial protection against oxidative stress in experimental animals (Shimazu et al. 2013). Alterations in histone signaling were also reported in alcohol-induced liver injury (Kendrick et al. 2010; Mandrekar 2011; Seth et al. 2011), but the role of histone acetylation in alcohol-induced hepatitis or cirrhosis is less
Fig. 6 The effect of arachidonic acid $(A A ; 60 \mu \mathrm{M})$ on oxidative stress in HepG2 and HepG2 cells overexpressing CYP2E1.

Oxidative stress was assessed 1 , $3,6,12$, and $24 \mathrm{~h}$ after AA treatment using flow cytometry detection of dichlorofluorescein diacetate fluorescence. The same AA treatment was done in cells grown prior to the treatment for 1 week in culture medium supplemented with $1 \mathrm{mM}$ acetate (Acetate $+A A)$ or $100 \mathrm{mM}$ ethanol $($ Ethanol $+A A)$. Mean DCF values after $24 \mathrm{~h}$ of AA treatments are also shown in Table 1

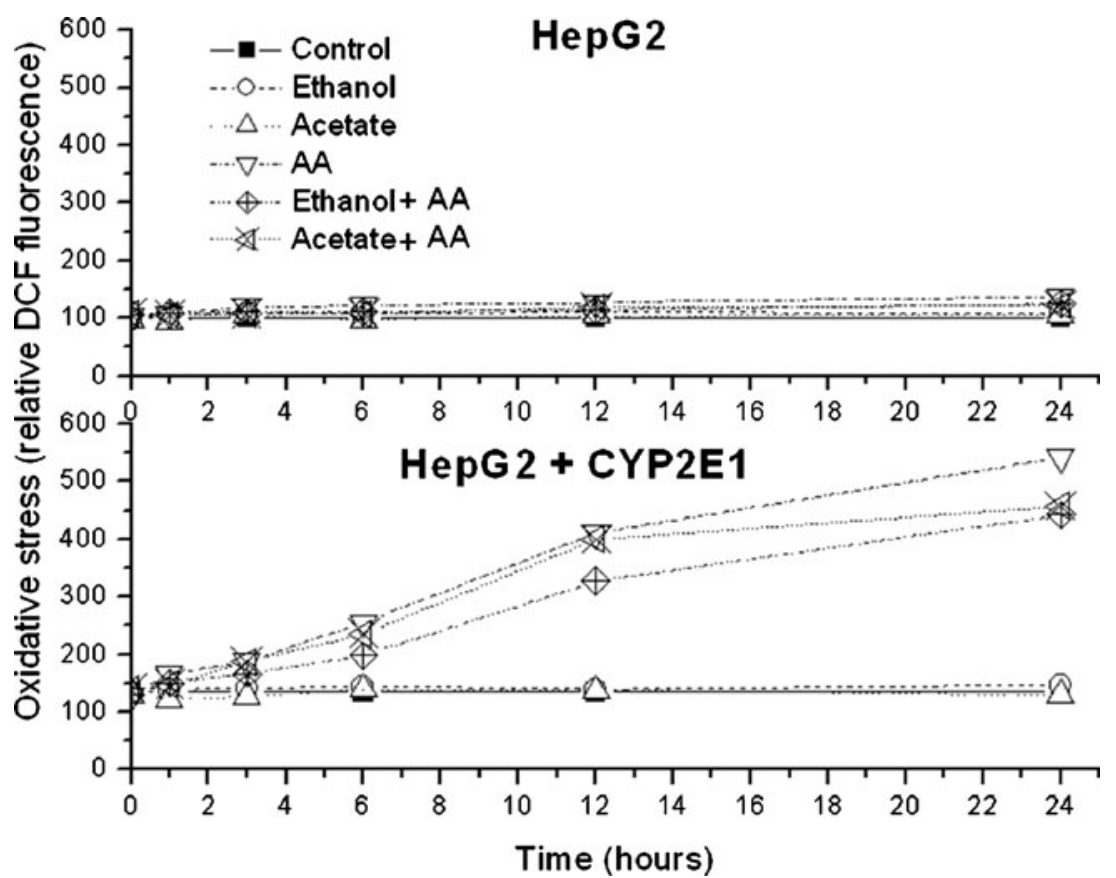


clear. Recent experimental evidences show that ethanol increases gene-selective association of acetylated H3-Lys 9 in the absence of global histone acetylation (Park et al. 2012). It was also shown that ethanol-induced acetylation of histone $\mathrm{H} 3$ in hepatocytes was related to oxidative stress (Choudhury et al. 2010). Liver cells are the main ethanol-metabolizing cells within the body; thus, ethanol generates oxidative stress mostly in hepatocytes. Ethanol-derived acetate can increase histone acetylation not only due to the elevated levels of ethanol-derived acetate but also by stimulation of histone acetyltransferases and inhibition of HDAC activity. HDACs are important regulators of many oxidative stress pathways including those involved with sensing and coordinating the cellular response to oxidative stress (Rahman et al. 2004). In our cells, decreased expression of relevant cytosolic HDAC isoenzyme HDAC2 was observed, in transduced cells treated with ethanol, although a tendency toward reduced HDAC protein levels could be observed also in cells grown with acetate. According to Agudelo et al. (2011), ethanol may increase HDAC2 expression in cultured neural cells, while in ischemia/reperfusion hepatocyte injury, activities of nuclear HDAC 1 and HDAC4 are significantly decreased (Evankovich et al. 2010). It seems that lower HDAC2 expression in our cells and possibly also lower HDAC activity may play a role in histone hyperacetylation and may be due to oxidative stress associated with CYP2E1 expression. On the other hand, it was shown that HDAC inhibitors protect neuronal cells from oxidative stress-induced damages (Langley et al. 2008) and against in vitro cytotoxicity (Kang et al. 2005), and it appear that such mechanism may be extended to other diseases that share both oxidative stress and inflammation. Our data confirm that HDAC inhibitors may act as antioxidants, since TSA significantly reduced oxidative stress induced by AA.

AA is involved in oxidative stress and in inflammatory response in alcohol-induced liver injury (Mottaran et al. 2002). AA metabolism proceeds mostly via the CYP450 pathway and generates epoxyeicosatrienoic acids and monohydroxylated products (Caro and Cederbaum 2006). Cultured hepatoblastoma cells grown in medium supplemented with AA have altered inflammatory gene expression but die due to oxidative stress ( $\mathrm{Xu}$ et al. 2003; Caro and Cederbaum 2006; Jimenez-Lopez et al. 2008). AA cytotoxicity can be definitely associated with the expression of ethanol metabolizing CYP450 isoenzyme-CYP2E1 (Caro and Cederbaum 2006; Jimenez-Lopez et al. 2008; Zhuge 2008), and our results confirm that AA cytotoxicity in HepG2 cells overexpressing CYP2E1 is mediated by oxidative stress, which is associated to CYP2E1 activity. However, when transduced cells were preincubated with ethanol or acetate, AA cytotoxicity was significantly lower or even abolished. Our data show that cells grown with ethanol or acetate have increases acetylated histone $\mathrm{H} 3$ while elevated acetylated histone H4 levels were detected only in transduced cells.
Our data confirm earlier reports (Marselos et al. 1987; Wu et al. 2006) indicating that HepG2 cells metabolize ethanol to acetate, and show that that both extracellular acetate and intracellular acetate generated in ethanol metabolism may increase histone acetylation. On the other hand, an increase in acetylated histones which was observed in our cells was rather limited comparing to other published data, since according to (Choudhury et al. 2010) ethanol applied for a few hours to cultured hepatocytes increases their acetylated $\mathrm{H} 3$ levels by three- to eightfold depending on time span of alcohol exposure and on ethanol concentrations. In this study, maximal increase of acetylated $\mathrm{H} 3$ was observed after $24 \mathrm{~h}$ of cells treatment (Choudhury et al. 2010). We were not able to detect hyperacetylated $\mathrm{H} 3$ and $\mathrm{H} 4$ histones in our cells treated with acetate or ethanol for $24 \mathrm{~h}$ (results not shown), but it appears that apart from different methods of histone isolation and analysis, histone acetylation may vary significantly between cell types and should be examined in each experimental setting.

We focused on general indices of cell growth, proliferation, cytotoxicity, and oxidative stress. AA was cytotoxic to both cell types, but remarkably higher toxicity was observed in CYP2E1 expressing cells. Such effect was already described in similar cellular models (Wu and Cederbaum 2009) and our data confirm that at relatively high AA concentrations there is substantial oxidative stress leading to necrotic cell death. AA cytotoxicity to transduced cells was significant already after about $3 \mathrm{~h}$ of exposure. In cells that did not express CYP2E1, similar cytotoxicity was attained after $24 \mathrm{~h}$ of AA treatment. Inhibition of CYP2E1 by 4MP or TSA significantly reduced or even abolished AA cytotoxicity, depending on the assay, confirming the role of CYP2E1 and histones in AA cytotoxicity. It should be noticed that plots of AA-induced LDH release reflecting cytotoxicity and plots of DCF fluorescence reflecting intracellular oxidative stress are very similar, although they reflect two distinct processes. DCF assay shows intracellular prooxidative changes that take place in viable cells while LDH release is reflecting cell membrane damage leading to cell death. Similar plots may indicate that oxidative stress plays a major role in cell death. It was previously shown that AA toxicity (both apoptotic and necrotic) in HepG2 cells expressing CYP2E1 may be abolished by free radical spin traps (Pérez and Cederbaum 2001) or by overexpression of antioxidant superoxide dismutase (Pérez and Cederbaum 2003). Apart from direct cytotoxicity, AA can alter intracellular signaling. It was shown that AA markedly increases AP-1 binding to DNA in HepG2 cells and this effect was potentiated by oxidative stress (Bai and Cederbaum 2000). Exogenous AA has also been shown to alter p38 mitogen-activated protein kinase pathway in neural cells (Wood et al 2000) and to induce $\mathrm{K}(+)$ efflux via $\mathrm{K}^{+}-\mathrm{Cl}^{-}$-cotransport in $\mathrm{HepG} 2$ cells (Lee 2009). Alterations in intracellular ion balance and kinase signaling may be important to cell growth and survival; 
however, at higher AA concentrations, such effects appear to be less relevant due to critical role of oxidative stress, cell membrane damage, and rapid necrotic cell death.

In our experiments, AA cytotoxicity was significantly lower in transduced cells, which prior to AA treatment had grown with ethanol or acetate but relatively low or even no cytotoxicity at all was also noticed in cells pretreated with 4MP or TSA. These data stress the role of CYP2E1 in mechanisms of AA cytotoxicity, but also point to the influence of histones which seem to play important role in survival of cells subject to oxidative stress. TSA is able to rapidly increase acetylated histone levels in cultured liver-derived cells (Carlisi et al. 2008) and in longer treatment it can induce apoptosis (Buurman et al. 2012). It was also shown that histone hypearcetylation can increase antioxidant defense (Zelko et al. 2011). AA metabolites are also able to change histone $\mathrm{H} 3$ and in some extent also histone $\mathrm{H} 4$ acetylation profile (Doyle and Fitzpatrick 2010). On the other hand, cyclooxygenase 1 involved in AA metabolism and inflammation is transcriptionally regulated by histone acetylation (Taniura et al. 2002). It is possible that in cells treated with external AA signaling pathways related to inflammation are significantly affected, but this mechanism seems to play a role in initial phases preceding cell membrane damage and should be studied in viable cells using more sensitive methods. Another possibly important observation is that AA produced also substantial but significant toxicity also in nontransduced HepG2 cells and this effect was not altered by preincubation of cells with ethanol or acetate which suggest another mechanism, possibly not related to oxidative stress.

In conclusion, our data show that histone hyperacetylation can, in some extent, protect the cells against oxidative stress and AA cytotoxicity. It is established that ethanol can generate oxidative stress at CY2E1 level. Our data indicate that ethanol metabolite - acetate, can shift histone acetylation toward hyperacetylation to act as antioxidant at histone level. This mechanism may be relevant in alcohol-induced liver injury.

Acknowledgments This work was supported by a Grant from the Medical University of Bialystok.

Open Access This article is distributed under the terms of the Creative Commons Attribution License which permits any use, distribution, and reproduction in any medium, provided the original author(s) and the source are credited.

\section{References}

Agudelo M, Gandhi N, Saiyed Z, Pichili V, Thangavel S, Khatavkar P, Yndart-Arias A, Nair M (2011) Effects of alcohol on histone deacetylase 2 (HDAC2) and the neuroprotective role of trichostatin A (TSA). Alcohol Clin Exp Res 35:1550-1556

Albano E (2006) Alcohol, oxidative stress and free radical damage. Proc Nutr Soc 65:278-290
Bai J, Cederbaum AI (2000) Overexpression of catalase in the mitochondrial or cytosolic compartment increases sensitivity of HepG2 cells to tumor necrosis factor-alpha-induced apoptosis. J Biol Chem 275: 19241-19249

Buurman R, Gürlevik E, Schäffer V, Eilers M, Sandbothe M, Kreipe H, Wilken L, Schlegelberger B, Kühnel F, Skawran B (2012) Histone deacetylases activate hepatocyte growth factor signaling by repressing microRNA-449 in hepatocellular carcinoma cells. Gastroenterology 143:811-820

Carlisi D, Vassallo B, Lauricella M, Emanuele S, D'Anneo A, Di Leonardo E, Di Fazio P, Vento R, Tesoriere G (2008) Histone deacetylase inhibitors induce in human hepatoma HepG2 cells acetylation of $\mathrm{p} 53$ and histones in correlation with apoptotic effects. Int J Oncol 32:177-184

Caro AA, Cederbaum AI (2006) Role of cytochrome P450 in phospholipase A2- and arachidonic acid-mediated cytotoxicity. Free Radic Biol Med 40:364-375

Cederbaum AI (2012) Alcohol metabolism. Clin Liver Dis 16:667-685

Chadee DN, Hendzel MJ, Tylipski CP, Allis CD, Bazett-Jones DP, Wright JA, Davie JR (1999) Increased Ser-10 phosphorylation of histone H3 in mitogen-stimulated and oncogene-transformed mouse fibroblasts. J Biol Chem 274:24914-24920

Choudhury M, Park PH, Jackson D, Shukla SD (2010) Evidence for the role of oxidative stress in the acetylation of histone $\mathrm{H} 3$ by ethanol in rat hepatocytes. Alcohol 44:531-540

Doyle K, Fitzpatrick FA (2010) Redox signaling, alkylation (carbonylation) of conserved cysteines inactivates class I histone deacetylases 1, 2, and 3 and antagonizes their transcriptional repressor function. J Biol Chem 285:17417-17424

Evankovich J, Cho SW, Zhang R, Cardinal J, Dhupar R, Zhang L, Klune JR, Zlotnicki J, Billiar T, Tsung A (2010) High mobility group box 1 release from hepatocytes during ischemia and reperfusion injury is mediated by decreased histone deacetylase activity. J Biol Chem 285:39888-39897

Jimenez-Lopez JM, Wu D, Cederbaum AI (2008) Synergistic toxicity induced by prolonged glutathione depletion and inhibition of nuclear factor-kappaB signaling in liver cells. Toxicol In Vitro 22:106115

Kang J, Chen J, Shi Y, Jia J, Zhang Y (2005) Curcumin-induced histone hypoacetylation: the role of reactive oxygen species. Biochem Pharmacol 69:1205-1213

Kendrick SF, O'Boyle G, Mann J, Zeybel M, Palmer J, Jones DE, Day CP (2010) Acetate, the key modulator of inflammatory responses in acute alcoholic hepatitis. Hepatology 51:1988-1997

Kirpich I, Ghare S, Zhang J, Gobejishvili L, Kharebava G, Barve SJ, Barker D, Moghe A, McClain CJ, Barve S (2012) Binge alcoholinduced microvesicular liver steatosis and injury are associated with down-regulation of hepatic Hdac 1, 7, 9, 10, 11 and up-regulation of Hdac 3. Alcohol Clin Exp Res 36:1578-1586

Langley B, D'Annibale MA, Suh K, Ayoub I, Tolhurst A, Bastan B, Yang L, Ko B, Fisher M, Cho S, Beal MF, Ratan RR (2008) Pulse inhibition of histone deacetylases induces complete resistance to oxidative death in cortical neurons without toxicity and reveals a role for cytoplasmic p21(waf1/cip1) in cell cycle-independent neuroprotection. J Neurosci 28:163-176

Lee YS (2009) Arachidonic acid activates K-Cl-cotransport in HepG2 human hepatoblastoma cells. Korean J Physiol Pharmacol 13:401408

Mandrekar P (2011) Epigenetic regulation in alcoholic liver disease. World J Gastroenterol 17:2456-2464

Mandrekar P, Szabo G (2009) Signalling pathways in alcohol-induced liver inflammation. J Hepatol 50:1258-1266

Marselos M, Strom SC, Michalopoulos G (1987) Effect of phenobarbital and 3-methylcholanthrene on aldehyde dehydrogenase activity in cultures of HepG2 cells and normal human hepatocytes. Chem Biol Interact 62:75-88 
Mottaran E, Stewart SF, Rolla R, Vay D, Cipriani V, Moretti M, Vidali M, Sartori M, Rigamonti C, Day CP, Albano E (2002) Lipid peroxidation contributes to immune reactions associated with alcoholic liver disease. Free Radic Biol Med 32:38-45

Niks M, Otto M (1990) Towards an optimized MTT assay. J Immunol Methods 130:149-151

Park PH, Miller R, Shukla SD (2003) Acetylation of histone H3 at lysine 9 by ethanol in rat hepatocytes. Biochem Biophys Res Commun 306:501-504

Park PH, Lim RW, Shukla SD (2012) Gene-selective histone H3 acetylation in the absence of increase in global histone acetylation in liver of rats chronically fed alcohol. Alcohol Alcohol 47:233-239

Pérez MJ, Cederbaum AI (2001) Spin trapping agents (Tempol and POBN) protect HepG2 cells overexpressing CYP2E1 against arachidonic acid toxicity. Free Radic Biol Med 30:734-746

Pérez MJ, Cederbaum AI (2003) Adenovirus-mediated expression of $\mathrm{Cu} /$ $\mathrm{Zn}$ - or Mn-superoxide dismutase protects against CYP2E1dependent toxicity. Hepatology 38:1146-1158

Rahman I, Marwick J, Kirkham P (2004) Redox modulation of chromatin remodeling: impact on histone acetylation and deacetylation, NFkappaB and pro-inflammatory gene expression. Biochem Pharmacol 68:1255-1267

Seth D, Haber PS, Syn WK, Diehl AM, Day CP (2011) Pathogenesis of alcohol-induced liver disease: classical concepts and recent advances. J Gastroenterol Hepatol 26:1089-1105

Shapiro HM (1988) Practical flow cytometry. Alan R Liss Inc, New York

Shepard BD, Tuma PL (2009) Alcohol-induced protein hyperacetylation: mechanisms and consequences. World J Gastroenterol 15:1219-1230

Shimazu T, Hirschey MD, Newman J, He W, Shirakawa K, Le Moan N, Grueter CA, Lim H, Saunders LR, Stevens RD, Newgard CB, Farese RV Jr, de Cabo R, Ulrich S, Akassoglou K, Verdin E (2013) Suppression of oxidative stress by $\beta$-hydroxybutyrate, an endogenous histone deacetylase inhibitor. Science 339:211-214
Taniura S, Kamitani H, Watanabe T, Eling TE (2002) Transcriptional regulation of cyclooxygenase- 1 by histone deacetylase inhibitors in normal human astrocyte cells. J Biol Chem 277:1682316830

Tsukamoto S, Kanegae T, Isobe E, Hirose M, Nagoya T (1998) Determinations of free and bound ethanol, acetaldehyde, and acetate in human blood and urine by headspace gas chromatography. Nihon Arukoru Yakubutsu Igakkai Zasshi 33:200-209

Ubezio P, Tivoli F (1994) Flow cytometric detection of hydrogen peroxide production induced by doxorubicin in cancer cells. Free Radic Biol Med 16:509-516

Wood MW, Segal JA, Mark RJ, Ogden AM, Felder CC (2000) Inflammatory cytokines enhance muscarinic-mediated arachidonic acid release through p38 mitogen-activated protein kinase in A2058 cells. J Neurochem 74:2033-2040

Wu D, Cederbaum AI (2009) Oxidative stress and alcoholic liver disease. Semin Liver Dis 29:141-154

Wu H, Cai P, Clemens DL, Jerrells TR, Ansari GA, Kaphalia BS (2006) Metabolic basis of ethanol-induced cytotoxicity in recombinant HepG2 cells: role of nonoxidative metabolism. Toxicol Appl Pharmacol 216:238-47-2

Xu Y, Leo MA, Lieber CS (2003) Lycopene attenuates alcoholic apoptosis in HepG2 cells expressing CYP2E1. Biochem Biophys Res Commun 308:614-618

Zelko IN, Stepp MW, Vorst AL, Folz RJ (2011) Histone acetylation regulates the cell-specific and interferon- $\gamma$-inducible expression of extracellular superoxide dismutase in human pulmonary arteries. Am J Respir Cell Mol Biol 45:953-961

Zentner GE, Henikoff S (2013) Regulation of nucleosome dynamics by histone modifications. Nat Struct Mol Biol 20:259-266

Zhuge J (2008) A decrease in S-adenosyl-L-methionine potentiates arachidonic acid cytotoxicity in primary rat hepatocytes enriched in CYP2E1. Mol Cell Biochem 314:105-112 